\title{
The Diagnostic and Therapeutic Challenges of Degloving Soft-Tissue Injuries
}

\author{
Rifat Latifi* \\ Department of Surgery, University of Arizona, USA
}

Received: November 08, 2013; Accepted: December 2, 2013; Published: December 16, 2013

"Corresponding authors: Rifat Latifi, Department of Surgery, University of Arizona, Arizona, USA, Tel: +974-4439-6716; Fax: +974-4439-4031; E-mail: rlatifi@email.arizona.edu

Degloving soft-tissue injuries are a form of avulsion of soft tissue, in which an extensive portion of skin and subcutaneous tissue detaches from the underlying fascia and muscles. Such injuries can affect every part of the body, but in particular the limbs (both upper and lower), trunk, face, and genitalia (Wójcicki, P., Wojtkiewicz, W. and Drozdowski, P., (2011)); [1,2,3] and can be associated with severe concomitant injuries and massive blood losses. Prompt recognition of degloving soft-tissue injuries is essential, yet treatment is time-consuming and often delayed. Thus, the injuries frequently progress to infection or even to necrotizing fasciitis. The severity of complications depends on the mechanism, the concomitant injuries, and the anatomic side affected and whether the degloving injuries are open or closed.

Degloving soft-tissue injuries are serious and potentially devastating. Many factors affect outcomes, such as the anatomic location, the force that caused the injury, and the presence of associated injuries. Early recognition is crucial.

The various classification patterns range from limited avulsion and minimal tissue loss to circumferential multiplane involvement of muscle groups and even of the periost. These patterns can occur either in isolation or, occasionally, in combination [4]. In addition, all degloving soft-tissue injuries including those of the pelvic girdle and lower extremities are classified as either open or closed (3). Among the most important types are Morel-Lavallée lesions (MLL), which are significant soft-tissue injuries associated with pelvic trauma [5-8]; however, they can also be present in other anatomic locations. MLL is most commonly seen in the greater trochanter and/or hip region (30\%), followed by thigh (20\%), pelvis (19\%), but can present in the knee $(16 \%)$, buttocks $(6 \%)$, lumbar vertebrae and sacral region $(3 \%)$, abdomen $(1.5 \%)$, calf $(1.5 \%)$, head $(0.5 \%)$, and other regions (2\%) [9-11]. Such lesions can be related to sports (14) or caused by motor vehicle collisions.

While degloving soft-tissue injuries can be present just about in every part of the body, the lower limb is the most commonly affected location and if not managed optimally, these injuries are associated with high rates of morbidity and mortality. Heel degloving injuries, upper-limb degloving injuries and severe scalp wounds tend to cause greater-than-expected blood loss, thereby contributing relatively quickly to patient destabilization. Degloving injuries involving the external genitalia, though uncommon, can be life threatening, with incapacitating and psychologically devastating consequences. Degloving injuries in children in particular, foot degloving injuries—can be serious and may require advanced complex surgical techniques to if functionality is to be restored.

\section{Diagnosis}

Degloving soft-tissue injuries are challenging to diagnose $[3,9]$. Clinical assessment of the degloved skin is a weak predictor of the extent of injury. Use of intravenous fluorescein may overestimate the line of demarcation between viable and nonviable skin [4]. After incomplete avulsion, subjective criteria (such as color, skin temperature, pressure reaction, and bleeding or lack of, can help determine skin viability.

Accurate diagnosis of Morel-Lavallée lesions is often delayed because of inconsistent clinical presentation and because initial skin bruising can mask the importance of the underlying softtissue injuries. This may be in particular a case in pigmented skin. In most patients, diagnosis is made from clinical detection of a fluctuant area combined with the findings of appropriate imaging modalities. Serum inflammatory markers sometimes are within the normal range [5]. Ultrasound, computed tomography (CT), and magnetic resonance imaging (MRI) are all useful tools for proper diagnosis, but MRI is the modality of choice for evaluating Morel-Lavallée lesions. The identification of a capsule on MRI can have important management implications.

\section{Treatment Principles}

Treatment of degloving soft-tissue injuries requires careful assessment of the extent of the devitalized tissue and the blood supply to the affected tissues. The general treatment principles include preservation of as much of each structure as possible, early primary definitive skin cover, good-quality skin cover, early return of function, and the necessity of any secondary procedures [3]. 
When the degloved skin is totally removed from the patient's body, it can be put back by a surgical procedure called replantation. This procedure, however, requires great expertise and vast resources. Furthermore, trauma patients may have other life-threatening injuries that do not allow for a lengthy replantation and revascularization procedure.

For patients with more limited degloving injuries with abrasion and/or avulsion, free tissue transfer procedures can be performed to cover any exposed underlying tendons, bones, and joints a skin flap, or a latissimus dorsi muscle flap covered with a skin graft have been suggested. Unfortunately, only a very few centers in the world can perform such types of tissue can be transferred; free tissue transfer procedures have also been limited by the need for expertise in microvascular surgery.

The avulsed skin has been used a source of (split- or fullthickness) skin grafts, combined with defatting of the avulsed skin with fenestration, followed by negative-pressure dressing. Extensive degloving injuries, more often than not, commit the patient to serial excisions before reconstruction. If the wound is too contaminated or too swollen, the avulsed tissue should be cleansed with pulsatile lavage, left with little or no tension, and addressed at a second exploration.

Degloving injuries associated with open fractures should be managed by comprehensive excision of devitalized hard and soft tissue, followed by appropriate skeletal fixation and the application of vascularized soft-tissue cover [4].

\section{Conclusion}

Degloving soft-tissue injuries are serious and potentially devastating. They require early recognition and early diagnosis. In the management of closed injuries in particular, a high index of suspicion remains crucial. A multidisciplinary approach is usually needed. Early reconstruction and effective rehabilitation are also essential to care for such patients. There is a need for multidisciplinary and multi-institutional study.

\section{References}

1. Wójcicki, P., Wojtkiewicz, W., \& Drozdowski, P. (2011). Severe lower extremities degloving injuries-medical problems and treatment results. Pol Przegl Chir, 83(5), 276-282.

2. Antoniou, D., Kyriakidis, A., Zaharopoulos, A., \& Moskoklaidis, S. (2005). Degloving Injury. European Journal of Trauma, 31(6), 593-596.

3. Krishnamoorthy, R., \& Karthikeyan, G. (2011). Degloving injuries of the hand. Indian J Plast Surg, 44(2), 227-236.

4. Arnez, Z.M., Khan, U., \& Tyler, M.P. (2010). Classification of soft-tissue degloving in limb trauma. J Plast Reconstr Aesthet Surg, 63(11), 18651869.

5. Archier, E., Grillo, J.C., Fourcade, S., Gaudy, C., Grob, J.J., \& Richard, M.A. (2012). Morel-Lavallée syndrome of the lower leg. Ann Dermatol Venereol, 139(3), 216-220.

6. Hudson, D.A. (1996). Missed closed degloving injuries: late presentation as a contour deformity. Plast Reconstr Surg, 98, 334-337.

7. Tseng, S., \& Tornetta, P. (2006). Percutaneous management of MorelLavallée lesions. J Bone Joint Surg Am, 88, 92-96.

8. Tsur, A., Galin, A., Kogan, L., \& Loberant, N. (2006). Morel-Lavallée syndrome after crush injury. Harefuah, 145, 111-113.

9. Hak, D.J., Olson, S.A., \& Matta, J.M. (1997). Diagnosis and management of closed internal degloving injuries associated with pelvic and acetabular fractures: the Morel-Lavallée lesion.J Trauma, 42(6), 10461051.

10. Kottmeier, S.A., Wilson, S.C., Born, C.T., Hanks, G.A., Iannacone, W.M., \& DeLong, W.G. (1996). Surgical management of soft tissue lesions associated with pelvic ring injury. Clin Orthop Relat Res, 329, 46-53.

11. Letournel, E., \& Judet, R. (1993). In: Elson RA, trans, (Eds.) Fractures of the Acetabulum. (2nd ed., pp 337-397). Berlin, Germany: Springer. 